\title{
Characterization of hot water spring source isolated clones of bacteria and their industrial applicability
}

\author{
Sudip Kumar Sen, Sudhir Kumar Mohapatra, Soumya Satpathy and Gopala Rao T.V. * \\ Department of Biotechnology, Gandhi Institute of Engineering and Technology, Gunupur-765 022, Rayagada District, \\ Orissa State, India, gopalraotv@yahoomail.com, Mobile +919437323511; Fax +916857250232
}

\begin{abstract}
A preliminary investigation was performed about the presence of industrially important thermophilic bacteria in the hot springs and in its vicinity near Beramhapur, Orissa state, India. Out of 20 to 30 clones, the randomly picked up two clones of bacterium samples, one each from a soil and water, had been taken for the laboratory experiments. The cells isolated from soil and water samples stained gram negative, is rod shaped and non acid-fast organism, and positive for endospore staining. The temperature range for growth at a $\mathrm{pH}$ of 7.5 was between $37.5^{\circ} \mathrm{C}$ and $60^{\circ} \mathrm{C}$ with optimum growth at $50^{\circ} \mathrm{C}$. Growth was inhibited by ampicillin, ciprofloxacin, cefadroxil and doxicycline, and cells showed positive protease, catalase and DNase activity, and lipase and oxidase activity was absent in them. The staining, morphological, biochemical, growth parameters, antibiotic studies proved that the bacteria are of gram negative and rod shaped nearer to the Escheritia coli cell type.
\end{abstract}

Keywords- thermophiles, bacteria, growth, biochemical assay, antibiotic assay

\section{Introduction}

Springs are the places where ground water is discharged at specific locations on the earth and they vary dramatically as to the type of water they discharge. Many of the springs are the result of long cracks or joints in sedimentary rock [1]. Hot springs are defined as springs where the temperature of water lies significantly above the mean of annual air temperature of that region. At rainy seasons, water descends behind it and forces the new heated water to ascend along the fault-line to surface as a hot or warm spring. If the water moves slowly from depth to the surface, it will cool back down before it bubbles out as a spring [2, 3]. However, many of these springs occur in limestone formations where the openings allow the water to the surface may create a virtual pipeline to the surface [4]. Hot springs contained the life even long before they reach the surface, and the warm water of the springs allows an abundant of algae and bacteria to survive which are called as thermophilic microorganisms $[5,6]$. These organisms live at hot temperatures, preferring to survive at those temperatures which are not normally found in nature. The thermophiles may among the first living things on the earth, developing and evolving during the primordial days of earth when surface temperatures were quite hot, and thus been called the "Universal Ancestor"[4, 5]. The hot spring which has been studied here is located on the eastern slope of the Eastern ghat in India, $51 \mathrm{kms}$ away from Berhampur, Orissa, which is a hot water sulfur spring set at the greenery of a lush forest. The sulfur spring of Taptapani is situated on the top of a hill in which the hot waters erupt in bubbles in two specific places and the temperature of this hot water varies between $37^{\circ} \mathrm{C}$ and $50^{\circ} \mathrm{C}$. In our study, we have initiated the survey of microbiological organisms of the Taptapani hot springs, which aims to characterize hot spring biodiversity using culture dependent techniques.

\section{Materials and Methods}

All the chemicals used for media, staining and other chemicals are of Himedia, Bombay, India. Soil and water samples were collected in a sterile wide-mouthed glass bottles and transported to laboratory where they were maintained at a temperature of $37.5^{\circ} \mathrm{C}$ for experimental analysis. Culture experiments by using Luria Bertani (LB) media which is composed of tryptone bacteriological (1\%), yeast extract $(0.5 \%)$, sodium chloride $(0.5 \%)$; distilled water added according to requirement. In case of solid media agar $(1.5 \%)$ was used. One pinch of soil, and $1 \mathrm{ml}$ of water sample, was added to $10 \mathrm{ml}$ of sterile distilled water separately. By serial dilution, an aliquot of various dilutions are added to the separate LB agar plates to spread at aseptic conditions and incubated at $37.5^{\circ} \mathrm{C}$. The plates with 50 to 60 colonies were taken for further study of characterization. Initially, the spread plate technique was used for the mixed population of microorganisms to isolate individual colonies. Randomly picked colonies had been taken for further study and for preservation as glycerol stock $[7,8]$. The standard gram staining technique had been performed with crystal violet and saffranine reagents for the differentiation of gram +ve or gram -ve of microorganisms (Aneja). The Ziehl-Neelsen stain was used for the acidfast stain, and the Schaeffer-Fulton method is used for endospore staining [7]. Standard methods were performed to get the biochemical characterization [7]. Presence of certain extra cellular enzymes was studied viz., protease, catalase, oxidase, DNase, and lipase on agar plates with streaks $[9,10]$. (a) Protease assay was done on agar plates supplemented with $10 \%$ 
double toned milk with over night incubation at $37^{\circ} \mathrm{C}$. (b) Catalase assay was by pouring drops of hydrogen peroxide directly over streaks on solid medium .(c) Oxidase assay was by putting of discs of cytochrome oxidase near to the streaks of agar plates. (d) DNase assay was by putting DNase agar with Toluidine blue added as supplement was used for detection of enzyme DNase. All the plates were left overnight at $37.5^{\circ} \mathrm{C}$ temperature in an incubator. Plates were observed for growth \& production of clearing zone around growth. Toluidine blue present as an indicator forms a complex with hydrolyzed DNA to produce bright zones surrounding colonies on a royal blue back ground [7].

\section{Determination of growth profile}

Effect of temperature (a physiological limiting factor) which governs the microbial cells multiplication, the culture was grown in LB broth in a water bath shaker at $150 \mathrm{rpm}$ at $37.5^{\circ} \mathrm{C}$, $45^{\circ} \mathrm{C}, 50^{\circ} \mathrm{C}$ and $60^{\circ} \mathrm{C}$ for optical density of 660 $\mathrm{nm}$ [9]. Second rate limiting step in growth is that the broth containing isolate was grown in either darkness, or in the presence of light, and in the third set was allowed to grow under alternative cycle of light and darkness of $1 \mathrm{hr}$ duration. In each set, after the entire growth cycle, the extent of growth was measured by checking the optical density at $660 \mathrm{~nm}$. Dark conditions were created by covering the glass incubator with a black cloth. The third rate limiting factor is that replacement of nitrogen source. Ammonium salts of LB were replaced by substrates like Casein Enzyme Hydrolysate, Tryptone bacteriological, Peptone type- 1 bacteriological at the same concentration, and growth was measured at $37^{\circ} \mathrm{C}$ for the optical density at $660 \mathrm{~nm}[8,10]$.

\section{Antibiotic assay}

Susceptibility towards different antibiotics was observed by using the discs on bacterial lawn of the agar plates incubated at $37^{\circ} \mathrm{C}$. After $48 \mathrm{hrs}$, the zone of inhibition was monitored against ampicillin, ciprofloxacin, cefadroxil, and doxicycline.

\section{Results and Discussion Morphological Characterization}

Gram stained strain obtained from the soil sample was carefully observed under microscope and was found to be as the bacteria and which were rod shaped and gram negative in nature. The bacteria obtained from the water sample when subjected to gram staining also reveal that the bacteria were rod shaped and gram negative. Both the soil and water bacteria are non acid-fast organisms in nature The Ziehl-Neelsen stain, also known as the acid-fast stain, resisted decolorization with acid-alcohol and stain red of the cells which is the color of the initial stain with carbol fuchsin. Acid-fast bacteria will appear red, non-acid-fast will not appear. On staining, they show the blue coloration. The bacterium present in soil sample are stained green indicating endospore staining. However, the bacterium present in water sample is stained color less which did not support the presence of endospores technique, and it uses Malachite green as the primary stain. Once the endospore has absorbed the stain, it is resistant to decolorization, but the vegetative cell is easily decolorized with water (leaving the vegetative cells colorless). Finally, the vegetative cells are counterstained with Safranin to aid in their visualization. When viewed under a microscope, the endospores appear green, while the vegetative cells are red (data not shown). As shown in table. 1 the biochemical characterization of all the enzymes activity was similar in the both cells of soil and water. The experimental study of enzymes showed the positive activity of protease, catalase, and DNase and negative activity of oxidase and lipase (Table.1). The biochemical characterization further revealed that both the soil and water were of gram negative and rod shape with a probability of Escheritia coli cell colonies (Figure.1)

\section{Physiological Characterization}

In order to find out tolerance of temperature factor, the strains of soil and water of the spring samples are initially subjected to different temperatures. The Table .2A and Table $2 \mathrm{~B}$ shows the Optical density (at $660 \mathrm{~nm}$ ) of the growth of bacterial samples of both the soil and water of the hot spring at different temperatures of $37.5^{\circ} \mathrm{C}, 45^{\circ} \mathrm{C}, 50^{\circ} \mathrm{C}$ and $60^{\circ} \mathrm{C}$ at $150 \mathrm{rpm}$ in water bath shaker along with the control. Both the samples were tolerable up to $60^{\circ} \mathrm{C}$ for $12 \mathrm{hrs}$ time period. For further experimentation of growth the range of temperatures were preferred between $37.5^{\circ} \mathrm{C}$ and $60^{\circ} \mathrm{C}$.

\section{Substrate Profile}

In order to find the prokaryotic microbe character, the growth of the culture in the following substrates is shown here. Soil bacterium was grown at $50^{\circ} \mathrm{C}$ and water bacterium was grown at $45^{\circ} \mathrm{C}$ as they were the optimum temperatures for growth. Bacterial growth was measured spectrophotometrically in terms of Optical density at $660 \mathrm{~nm}$. As shown in the table 3, the substrate supplemented as alternative nitrogen source has given constant increase in the growth of soil and water samples. However, the water sample had shown the more percentage of growth than the sample of soil.

\section{Antibiotic Sensitivity}

The sensitivity profiles of the isolates from the soil and water samples towards different antibiotics are shown below in figure.2. The resistance and tolerance towards different 
antibiotics gives an idea of the nature of the isolates. Since all the antibiotics used are antibacterial one can conclude that plasmid containing prokaryotic cells are evident in this isolation and characterization. In the series of studies from morphological, biochemical, substate supplementation and antibiotic assay revealed that the isolate is a kind of strain of E.coli which can tolerate the temperature up to $60^{\circ} \mathrm{C}$ and got the character of thermophilic.

\section{Growth curve}

For growth profile, test tubes containing culture which was grown overnight in an orbital shaker at $37.5^{\circ} \mathrm{C}$ was used as inoculums (with volume of $1.5 \mathrm{ml}$ ) to inoculate in to fresh conical flasks of $50 \mathrm{ml}$ medium and was incubated at specific temperatures in water bath shaker at $150 \mathrm{rpm}$ and optical density was taken at every hour to determine the growth. As shown in Figure.2A and $2 \mathrm{~B}$ the growth of both the soil and water samples were recorded against time at different temperatures by measuring the optical density. With more or less differences, both soil and water have shown the similar pattern of growth. The soil cells at $37.5^{\circ} \mathrm{C}$ have shown normal sigmoid growth curve with mid log of 16 hours. At higher temperatures at $45^{\circ} \mathrm{C}$ and $50^{\circ} \mathrm{C}$ have also shown perfect sigmoid with early stationary. At $60^{\circ} \mathrm{C}$ growth is very minute maintained lag phase. As shown in figure $2 \mathrm{~B}$ the growth of water sample bacteria at $37.5^{\circ} \mathrm{C}, 45^{\circ} \mathrm{C}$, and $50^{\circ} \mathrm{C}$ was more and fastened the stationary very early. This is may be due to the stationary phase cells, inoculum's volume has given the perfect early sigmoid curve which was not shown in soil sample. However, at $60^{\circ} \mathrm{C}$ the growth was poor and maintained lag phase only. It can be concluded that in this spring of Taptapani, Orissa, India, the heat resistant microbial fauna is available. The enzyme and enzyme complexes must be plenty for their cell division and survival up to $60^{\circ} \mathrm{C}$. These enzymes and enzyme complexes sources may be useful for our wet laboratory studies of molecular biology. By the results of growth curve, we can expect the presence of enzymes which may mimic the activity of Taq polymerase enzyme from thermophiles. The applicability of enzymes for molecular biology experiments is not a secondary thing. This rod shaped bacteria can be a good source of enzymes of transcription, translation, and cell division. The lowest growth temperature for the isolates obtained from the soil sample of the hot Springs was $37.5^{\circ} \mathrm{C}$ and the growth was evident up to $50^{\circ} \mathrm{C}$, with very weak growth seen at $60^{\circ} \mathrm{C}$. Similarly the lowest growth temperature for the isolates obtained from the water sample of the hot springs was $37.5^{\circ} \mathrm{C}$ and optimum growth was evident at $45^{\circ} \mathrm{C}$ with a very weak growth seen at $60^{\circ} \mathrm{C}$. As shown in figure $2 \mathrm{C}$, in order to find the effect of light on growth of this rod shaped bacteria, both the soil and water samples were subjected to growth at continuous dark, alternative dark and light for a period of one hour at each step, and continuous light. In light the optimum temperature for growth of the soil sample bacterium as observed in growth profiling is $50^{\circ} \mathrm{C}$. So as the effect of light/dark on growth will be observed at $50^{\circ} \mathrm{C}$ for the soil sample. Again the effect of light, the optimum temperature for growth of bacterium present in water sample has been observed to be $45^{\circ} \mathrm{C}$. Further, the effect of light/dark on growth will be observed at $45^{\circ} \mathrm{C}$ for the water sample. Thus, from the growth curve (Figure. 2C), it was observed that both the soil and water samples exhibited the best growth in the presence of light and lowest growth in dark conditions, with intermediate growth in alternate light and dark conditions.

\section{Conclusion}

The thermophiles survive at relatively high temperatures, between $45^{\circ} \mathrm{C}$ and $80^{\circ} \mathrm{C}$, and are classified as obligate and facultative. Obligate thermophiles (or extreme thermophiles) require such high temperatures for growth, whereas facultative thermophiles (also called moderate thermophiles) can thrive at high temperatures but also at lower temperatures (below $50^{\circ} \mathrm{C}$ ). Hyperthermophiles are particularly extreme thermophiles for which the optimal temperatures are above $80^{\circ} \mathrm{C}$. For their survival, thermophiles contain enzymes that can function at their survival temperatures. Some of these enzymes are used in research of molecular biology (for example, heat-stable DNA polymerases for PCR), and got the industrial applications [11].

\section{Acknowledgements}

The authors are very much thankful to management of GIET, Gunupur-765022, for the facilities provided for this paper.

\section{References}

[1] Young M.C. (2008) Aqua Thermal Access, ISBN 1-890880-08, pp.6.

[2] Thompson C.(2003) The Arizona Republic, 1-12-03, pp B12.

[3] Young M.C. (2007) Aqua Thermal Access, ISBN 1-890880-07, pp.8.

[4] Woese C.R. (1998) Proc. Natl. Acad. Sci., 284, 2124-2128.

[5] Austain B. (1988) In Book A Wiley-Inter Sci. pubn. 222-231.

[6] Woodsworth G.J. (1999) Godon Soules Book Pub. ISBN 0-91957 4-03-3.

[7] Aneja K.R. (2003) In a book, New Age Publin. India pp 74-294.

[8] Sarkar A., Roy A., Pal S., Prakashi S., Mahra P.K., Sahoo S., Dev A., Mishra M., Sen S.K., Thakur A.R. and Chouduri S.R. (2008) Online.J.Biol.Sci., 8 (2),3240. 
[9] Doolittle W.F. (1999) Science, 284, 21242128.

[10] Nandy P., Thakur A.R. and Chaushuri, S.R.(2007) Online.J.Biol.Sci., 7, 44-51.
[11] Fujio Y. and Kume S. (1991) World J. Microb. \& Biotech.7, 12-16.

Table 1- Biochemical characterization of different enzymes of soil and water isolates. As shown in materials and methods the enzymes assay were performed and observed the presence and absence of activity.

\begin{tabular}{|l|r|l|r|r|l|}
\hline SAMPLE & Protease & Oxidase & Catalase & \multicolumn{1}{l|}{ Lipase } & DNase \\
\hline SOIL & $+\mathrm{ve}$ & -ve & $+\mathrm{ve}$ & $-\mathrm{ve}$ & $+\mathrm{ve}$ \\
\hline WATER & $+\mathrm{ve}$ & -ve & $+\mathrm{ve}$ & $-\mathrm{ve}$ & $+\mathrm{ve}$ \\
\hline
\end{tabular}

Table 2A,B-Temperature tolerance at different temperatures. The culture grown at different temperatures as above shown in table and optical density was taken to see the tolerable temperature.

\begin{tabular}{|c|c|c|c|c|}
\multicolumn{5}{c|}{$A$} \\
\hline $\mathrm{Hr}$ & $37.5^{\circ} \mathrm{C}$ & $45^{\circ} \mathrm{C}$ & $50^{\circ} \mathrm{C}$ & $60^{\circ} \mathrm{C}$ \\
\hline 12 & 0.016 & 0.034 & 0.069 & 0.058 \\
\hline \multicolumn{5}{|c|}{$\mathrm{B}$} \\
\hline $\mathrm{Hr}$ & $37.5^{\circ} \mathrm{C}$ & $45^{\circ} \mathrm{C}$ & $50^{\circ} \mathrm{C}$ & $60^{\circ} \mathrm{C}$ \\
\hline 12 & 0.092 & 0.073 & 0.064 & 0.058 \\
\hline
\end{tabular}

Table 3- Growth of soil and water samples in substituted nitrogen sources instead of the nitrogen source of LB medium. Both the soil and water samples are able to grow on nitrogen source offered by CEH:Casein Enzyme Hydrolysate, TB: Tryptone bacteriological, and PB : Peptone type-1 bacteriological.

\begin{tabular}{|l|c|c|c|c|c|c|}
\hline Hrs & \multicolumn{2}{|c|}{ CEH } & \multicolumn{2}{c|}{ TB } & \multicolumn{2}{c|}{ PB } \\
\hline & Soil & Water & Soil & Water & Soil & Water \\
\hline 0 & 0.032 & 0.845 & 0.049 & 0.805 & 0.038 & 0.693 \\
\hline 1 & 0.048 & 1.147 & 0.057 & 1.147 & 0.042 & 0.893 \\
\hline 2 & 0.129 & 1.863 & 0.086 & 1.369 & 0.056 & 0.912 \\
\hline
\end{tabular}


A

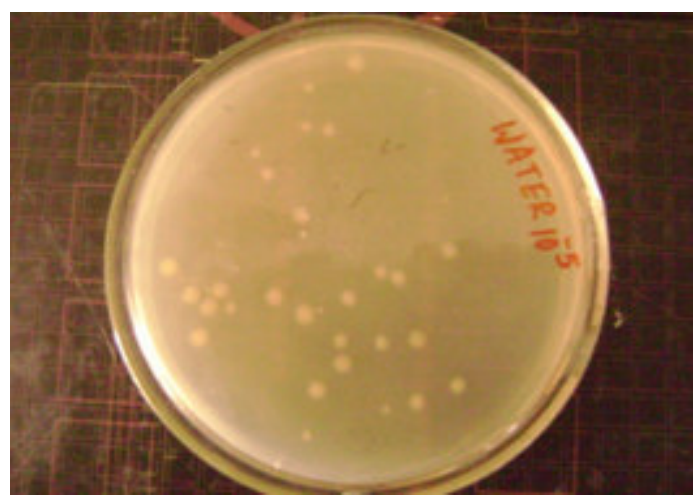

C
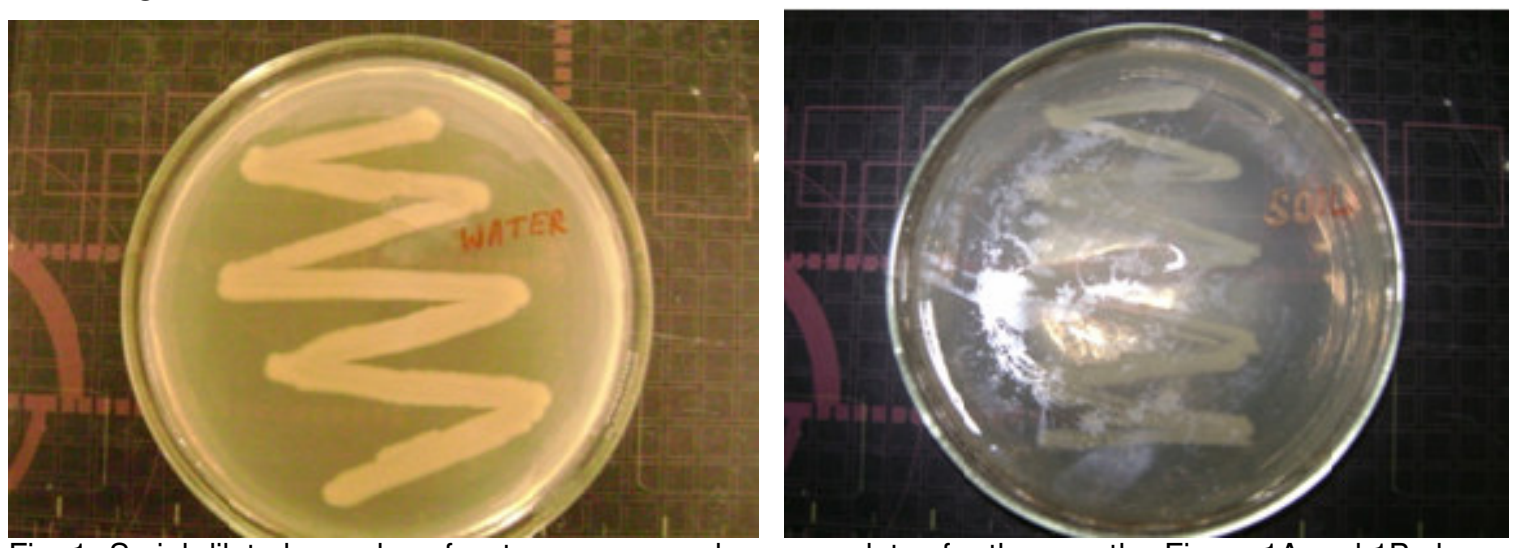
the water samples making colonies of prokaryote bacteria. Figure 1C and 1D shows the streaks of water and soil samples of randomly picked clones. 
A
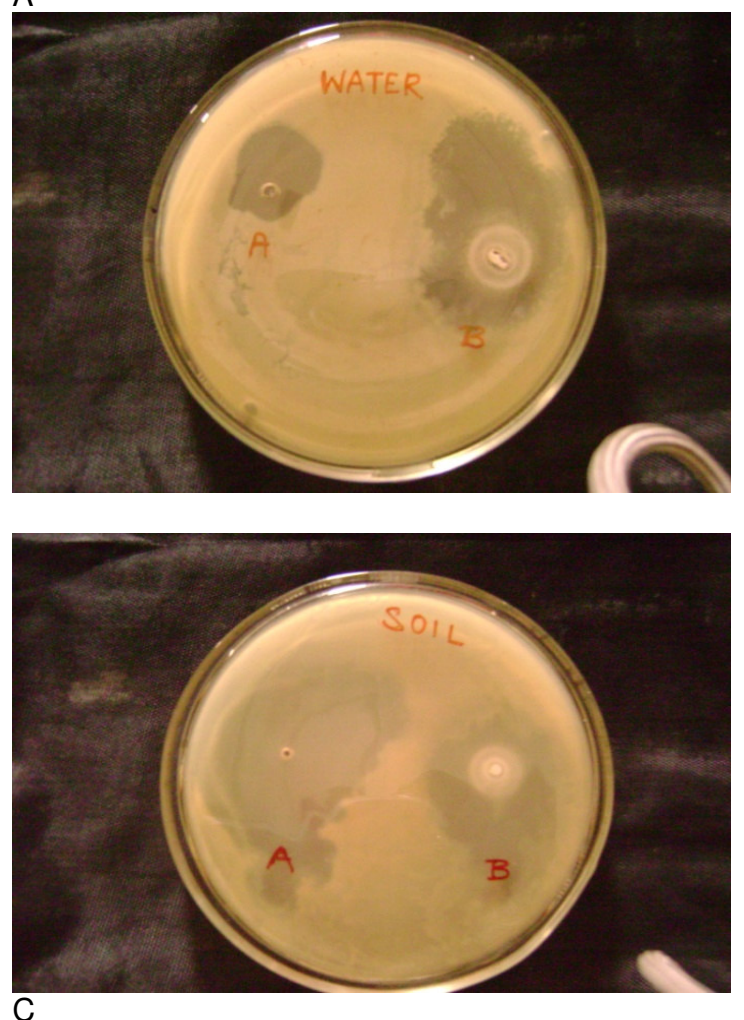

B
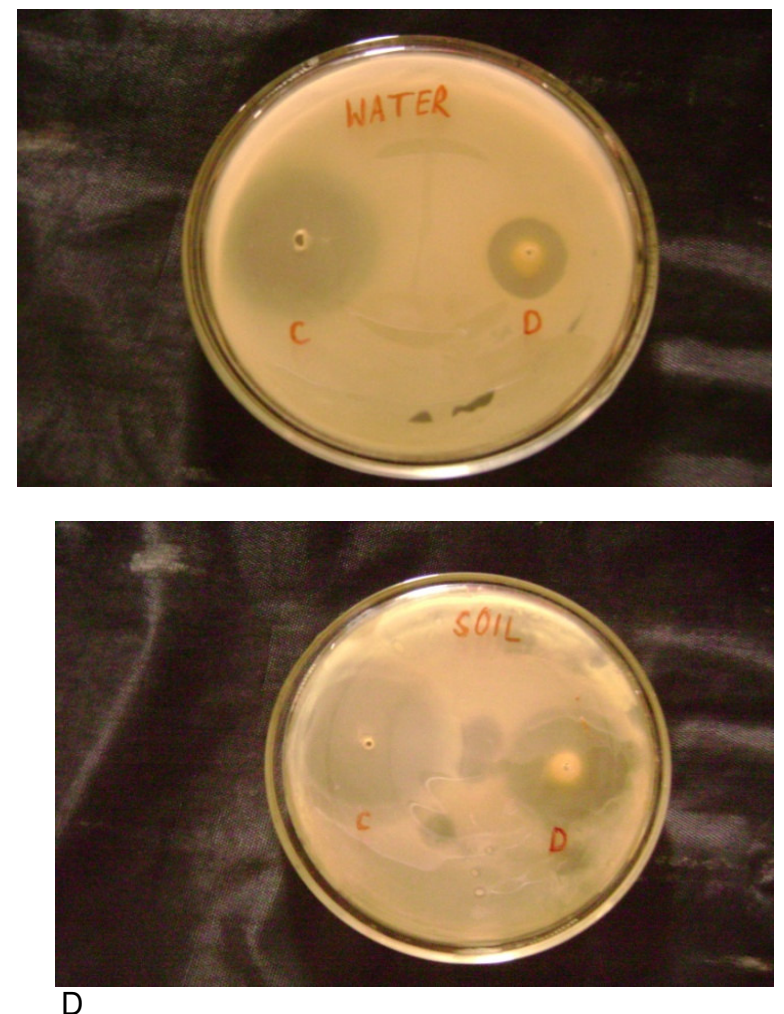

Fig. 2- Figure 2A, 2B, 2C, and 2D show the zone of inhibition of antibiotics by the bacteria isolated from water and soil samples of hot spring area. Fig $3 \mathrm{~A}$ and $3 \mathrm{~B}$ shows $\mathrm{A}$ ampicillin with $.07 \mathrm{~cm}$, and $\mathrm{B}$ ciprofloxacin with $1.0 \mathrm{~cm}, C$ cefadroxil with $1.5 \mathrm{~cm}$, and $D$ doxycycline with $0.9 \mathrm{~cm}$, of the water sample.

Figure $3 \mathrm{C}$ and 3D shows that zone of inhibition in soil sample. A ampicillin with $1.6 \mathrm{~cm}, \mathrm{~B}$ ciprofloxacin with $1.4 \mathrm{~cm}$, C cefadroxil with $2.0 \mathrm{~cm}$., D doxicycline with $1.2 \mathrm{cms}$. 
A

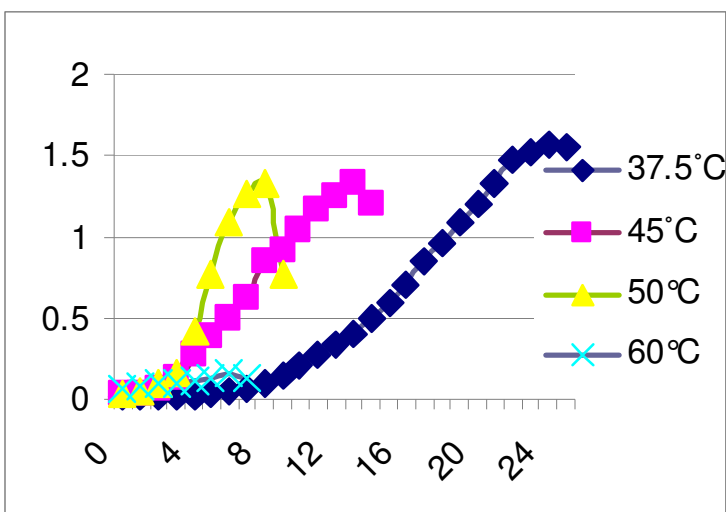

B

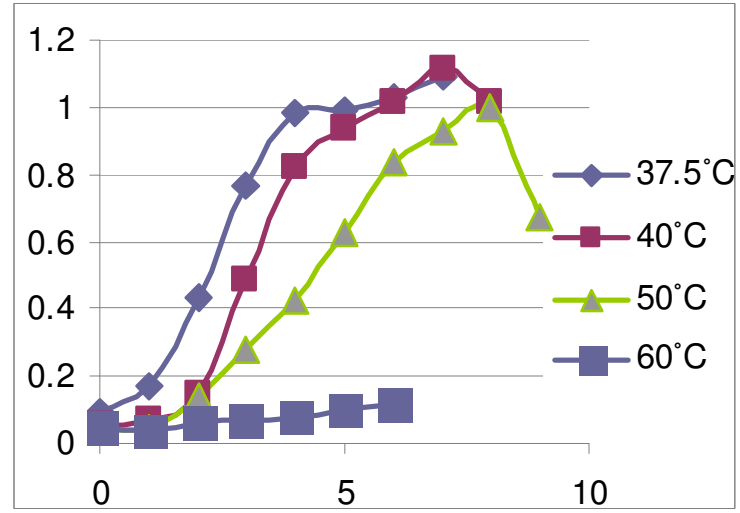

C Effect of light/ light-dark/ dark on growth

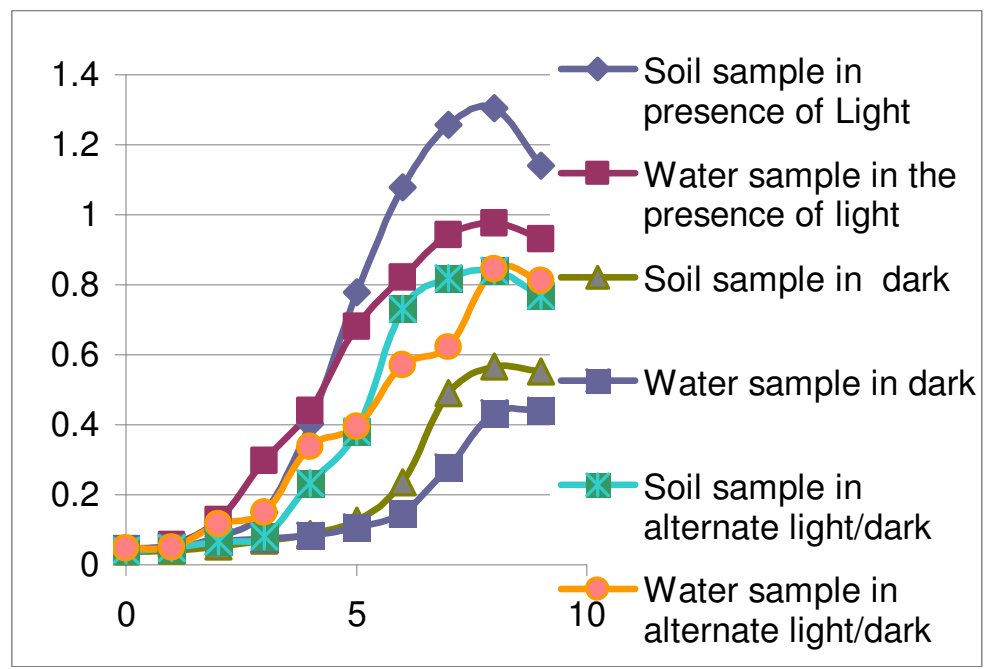

Fig. 3- Growth curve of bacteria, characterized as E.coli isolated from soil and water of a hot spring; 3AGrowth curve at different temperatures from soil sample; 3B- Growth curve at different temperatures from water sample; 3C- Growth curve at different temperatures from soil and water at light, dark, and light/dark as shown in materials and methods; $X$-axis is time in hours and $Y$-axis is optical density. 